\title{
EFEK ANTIINFLAMASI EKSTRAK ETANOL DAUN KAMBOJA (Plumeria rubra L.) PADA TIKUS PUTIH (Rattus norvegicus)
}

\author{
Safriani Rahman, Aulia Wati, Ema Sukmawati \\ Fakultas Farmasi, Universitas Muslim Indonesia, Makassar \\ Email : safriani.rahman@umi.ac.id
}

\begin{abstract}
Inflammation is a body protective response against tissue injury which can be characterizet by the formation of edema. Frangipani Leaves contain flavanoids, saponins and alkaloids. The flavanoid compound is considered to have a useful effect for healing edema. This research aimed to examine the effects of antiinflamatory and determined the dose of ethanol extract of the frangipani leaves (Plumeria rubra L.) as an anti-inflammatory in the rat. The test of anti-inflammatory effect was done by using the Rat Hind Paw Edema method in which test animals it used 15 rats divided into 5 groups: groups I (negative control) was given Na.CMC $1 \% \mathrm{w} / \mathrm{V}$, group II (positive control) was given diclofenac sodium, group III, IV and V were given the ethanol extract of the frangipani leaves successive doses of $166,6 \mathrm{mg} / \mathrm{kgBW}, 222,2 \mathrm{mg} / \mathrm{kgBW}$, and $277,7 \mathrm{mg} / \mathrm{kgBW}$, all groups were orally administered. The tested animals were induced carrageenan $1 \% \mathrm{w} / \mathrm{v}$ in intraplantar $0,5 \mathrm{~mL}$ and were meansured their foot edema volume before performed before induction as the intial volume (Vo), after induction, and 1 hour after the administration of the dosage form for 5 hours with the intervals of 1 hours using the pletismometer. The research result data were proccessed statistically using on-wey anova. Based of the data analysis showed that the ethanol extract of the frangipani leaves have the activity as the anti-inflammatory and statistically, the assay extract group showed the result not significantly different $(p>0,05)$ against the diclofenac sodium group and a dose of $277,7 \mathrm{mg} / \mathrm{kgBW}$ possessed the best activity compared to a dose of $166,6 \mathrm{mg} / \mathrm{kgBW}$ and $222,2 \mathrm{mg} / \mathrm{kgBW}$.
\end{abstract}

Key words : Anti-inflammatory, Plumeria rubra L., frangipani leaves, diclofenac sodium.

\section{PENDAHULUAN}

Inflamasi adalah usaha tubuh

untuk menginaktivasi atau menghancurkan organisme penginvasi, menghilangkan iritan, dan persiapan tahapan untuk perbaikan jaringan. ${ }^{1}$ Penyebab inflamasi antara lain mikroorganisme, trauma mekanis, zat-zat kimia, dan pengaruh fisika yang ditandai dengan gejala seperti rubor (kemerahan), kalor (panas), dolor (nyeri), dan tumor (pembengkakan). ${ }^{2}$

Pengobatan inflamasi dapat dilakukan dengan obat-obat kimiawi yang memberikan proses 
Efek antiinflamasi ekstrak etanol daun kamboja (ㄹlumeria rubra L.) pada tikus putih (Rattus norvegicus)

penyembuhan yang cepat untuk mengurangi rasa nyeri dan memperlambat proses perusakan jaringan. Kelompok obat yang banyak diberikan adalah obat antiinflamasi non steroid (AINS). ${ }^{3} \quad$ Namun penggunaan obat-obat tersebut menimbulkan gangguan saluran pencernaan serta iritasi lambung.

Salah satu tanaman yang telah banyak dikenal dan digunakan secara luas oleh masyarakat Indonesia adalah kamboja (Plumeria rubra L.). Daun kamboja (Plumeria rubra L.) mengandung, flavonoid, polifenol dan alkaloid. ${ }^{4}$ Manfaat flavanoid antara lain adalah untuk melindungi struktur sel, memiliki hubungan sinergis dengan vitamin C (meningkatkan efektivitas vitamin $\mathrm{C}$ ), mencegah keropos tulang, antibiotik dan sebagai antiinflamasi. ${ }^{6}$

\section{METODE PENELITIAN}

\section{Jenis penelitian}

Jenis penelitian yang dilakukan adalah penelitian secara eksperimental yang merupakan penelitian laboratorium dengan menggunakan metode Rat Hind Paw Edema dan menggunakan alat pletismometer.

\section{Alat dan bahan}

Alat-alat yang digunakan adalah cawan porselin, gelas arloji, gelas kimia, labu ukur, kanula, pipet tetes, pletismometer, spoit, stirer, timbangan analitik (Ohaus), timbangan hewan. Bahan yang digunakan yaitu ekstrak etanol daun kamboja (Plumeria rubra L.), aquadest, etanol $96 \%$, karagen $1 \%$, natrium karboksimetil selulosa ( $\mathrm{Na} \mathrm{CMC}$ ), natrium diklofenak, $\mathrm{NaCl}$.

\section{Prodsedur kerja}

Pembuatan suspense Na.CMC $1 \mathbf{b} / \mathbf{v}$

Na.CMC ditimbang sebanyak 1 gram, dimasukkan sedikit demi sedikit kedalam $50 \mathrm{~mL}$ air suling panas (suhu $70^{\circ} \mathrm{C}$ ) sambil diaduk dengan menggunakan pengaduk elektrik hingga terbentuk larutan koloidal yang homogen, kemudian dicukupkan volumenya hingga $100 \mathrm{~mL}$ dengan air suling.

\section{Pembuatan suspensi karagen $1 \%$}

Karagen ditimbang sebanyak 0,1 gram ditambahkan larutan $\mathrm{NaCl} 5$ $\mathrm{mL}$, dihomogenkan kemudian dicukupkan volumenya hingga $10 \mathrm{~mL}$.

\section{Pembuatan bahan pembanding} suspensi natrium diklofenak $\mathbf{5 , 1 3 8}$ $\mathrm{mg} / \mathrm{kgBB}$

Natrium diklofenak ditimbang sebanyak 5,138 mg yang kemudian dimasukkan ke dalam lumpang, ditambahkan larutan koloidal Na.CMC $1 \%$ sedikit demi sedikit sambil digerus hingga homogen lalu dimasukkan ke 
Efek antiinflamasi ekstrak etanol daun kamboja (ㄹlumeria rubra L.) pada tikus putih (Rattus norvegicus)

dalam labu tentukur $10 \mathrm{~mL}$ dan volumenya dicukupkan sampai $10 \mathrm{~mL}$.

\section{Pembuatan ekstrak daun kamboja}

Daun kamboja (Plumeria rubra L.) yang telah kering ditimbang sebanyak 200 gram dimasukkan ke dalam wadah mesarasi, kemudian di tambahkan pelarut etanol $96 \%$ sebanyak 2.000 mLkedalam wadah hingga terendam dan biarkan selama 3 hari dalam wadah tertutup rapat dan terhindar dari cahaya matahari sambal diaduk berulang-ulang. Setelah $3 \times 24$ jam simplisia disaring dan ampasnya direndam kembali dengan pelarut yang baru. Hal ini dilakukan sebanyak 3 kali.Hasil saringa diuapkan hingga menjadi ekstrak etanol kental.

\section{Pembuatan sediaan uji ekstrak daun} kamboja

Sediaan uji ekstrak daun kamboja (EEDK) yang digunakan adalah EEDK dosis $166,6 \mathrm{mg} / \mathrm{kgBB}$, 222,2 mg/KgBB, dan 277,7 mg/kgBB. Untuk membuat sediaan EEDK dengan dosis $166,6 \mathrm{mg} / \mathrm{kgBB}$ adalah ditimbang 166,6 mg ekstrak kemudian dilarutkan dalam Na.CMC sebanyak $10 \mathrm{~mL}$ dan diaduk homogen. Untuk EEDK dosis $222,2 \mathrm{mg} / \mathrm{kgBB}$ dan 277,7 $\mathrm{mg} / \mathrm{kgBB}$ masing-masing ditimbang 222,2 mg dan 277,7 mg ekstrak kemudian dilarutkan dalam Na.CMC sebanyak $10 \mathrm{~mL}$ dan diaduk hingga homogen.

\section{Pemilihan dan pemeliharaan hewan uji}

Hewan uji yang digunakan dalam penelitian adalah tikus (Rattus Norvegicus) yang sehat dengan bobot 150-200 gram sebanyak 15 ekor. Dibagi dalam 5 kelompok, masingmasing terdiri dari 3 ekor. Sebelum diberi perlakuan tikus diadaptasi selama \pm 14 hari dengan pemberian pakan standar.

\section{Perlakuan terhadap hewan uji}

Tikus (Rattus norvegicus) diadaptasi dalam kandang kurang lebih selama satu minggu untuk proses aklimatisasi.Hewan uji dibagi dalam 5 kelompok dengan jumLah 3 ekor pada masing-masing kelompok. Kelompok I (kontrol) diberi Na.CMC, kelompok II (pembanding) diberikan suspensi natrium diklofenak, kelompok III, IV dan V diberikan ekstrak etanol daun kamboja dengan dosis masingmasing 166,6 mg/kgBB, 222,2 $\mathrm{mg} / \mathrm{kgBB}$ dan $277,7 \mathrm{mg} / \mathrm{kgBB}$. Untuk menguji kemampuan ektrak etanol daun kamboja sebagai antiinflamasi maka diujikan kehewan uji tikus. Tikus dipuasakan selama 8 jam sebelum perlakuan, namun air minum tetap diberikan kemudian ditimbang berat badannya. Setiap kelopok hewan uji 
Efek antiinflamasi ekstrak etanol daun kamboja (ㄹlumeria rubra L.) pada tikus putih (Rattus norvegicus)

diinduksi dengan karagen sebanyak 0,5 mL Pengukuran dilakukan sebelum induksi, setelah induksi, dan setelah perlakuan pada jam ke 1, 2, 3, 4 dan 5.

\section{Penentuan Volume Edema}

Pengukuran volume edema pada telapak kaki tikus dilakukan dengan cara menceupkan kaki mencit kedalam pletismometer setiap selang waktu 1 jam menit selama 5 jam, yaitu pada jam ke 1, 2, 3, 4 dan 5 . Kemudian dilihat volume inflamasi berdasarkan kenaikan raksa pada pletismometer.

\section{Analisis data}

Data yang diperoleh dari ukuran volume edema telapak kaki tikus

mencit setiap waktu pada semua kelompok ditabulasikan, kemudian dihitung rata-rata volume kaki inflamasi dan rata-rata penurunan edema kaki tikus dilakukan dengan membandingkan terhadap volume dasar sebelum penyuntikan karagen. Selanjutnya hasil yang diperoleh dari perhitungan dianalisis denan One Way ANOVA, kemudian dilanjtkan dengan uji LSD untuk melihat perbedaan antara perlakuan signifikan $(p>0,05)$ atau tidak signifikan $(p<0,05)$.

\section{HASIL PENELITIAN}

Hasil penelitian efek
antiinflamasi ekstrak etanol daun
kamboja (Plumeria rubra L.) dapat
dilihat pada table 1 di bawah ini :

Tabel 1. Rata-rata hasil pengukuran volume edema $(\mathrm{mL})$ pada pletismometer setelah perlakuan (Jam)

\begin{tabular}{|c|c|c|c|c|c|c|c|}
\hline \multirow{2}{*}{ Perlakuan } & \multirow{2}{*}{$\begin{array}{l}\text { Vol. } \\
\text { Awal }\end{array}$} & \multirow{2}{*}{$\begin{array}{c}\text { Vol. } \\
\text { Induksi }\end{array}$} & \multicolumn{5}{|c|}{ Setelah perlakuan (Jam) } \\
\hline & & & 1 & 2 & 3 & 4 & 5 \\
\hline $\begin{array}{c}\text { KLP I } \\
\text { (Na.CMC) }\end{array}$ & 2,26 & 3,46 & 3,43 & 3,39 & 3,36 & 3,32 & 3,29 \\
\hline $\begin{array}{l}\text { KLP II Natrium } \\
\text { diklofenak }\end{array}$ & 2,34 & 3,42 & 3,28 & 3,39 & 2,96 & 2,75 & 2,55 \\
\hline $\begin{array}{c}\text { KLP III (EEDK } \\
166,6 \mathrm{mg} / \mathrm{kgBB})\end{array}$ & 2,42 & 3,51 & 3,41 & 3,32 & 3,24 & 3,15 & 3,07 \\
\hline $\begin{array}{c}\text { KLP IV (EEDK } \\
222,2 \mathrm{mg} / \mathrm{kgBB})\end{array}$ & 2,62 & 3,85 & 3,65 & 3,53 & 3,42 & 3,31 & 3,19 \\
\hline $\begin{array}{c}\mathrm{KLP} \vee(\text { V (EEDK } \\
277,7 \mathrm{mg} / \mathrm{kgBB})\end{array}$ & 2,49 & 3,72 & 3,57 & 3,43 & 3,28 & 3,14 & 2,99 \\
\hline
\end{tabular}


Efek antiinflamasi ekstrak etanol daun kamboja (lumeria rubra L.) pada tikus putih (Rattus norvegicus)

Tabel 2. Rata-rata persen penurunan volume edema (\%)

\begin{tabular}{cccccc}
\hline \multirow{2}{*}{\begin{tabular}{c} 
Kelompok perlakuan \\
\cline { 2 - 6 }
\end{tabular}} & $\mathbf{1}$ & $\mathbf{2}$ & $\mathbf{3}$ & $\mathbf{4}$ & $\mathbf{5}$ \\
\hline $\begin{array}{c}\text { Na.CMC } \\
1 \% \mathrm{~b} / \mathrm{v}\end{array}$ & 0,86 & 2,02 & 2,89 & 4,04 & 4,91 \\
\hline $\begin{array}{c}\text { Natrium Diklofenak } \\
\begin{array}{c}\text { EEDK } \\
166,6 \mathrm{mg} / \mathrm{kgBB}\end{array}\end{array}$ & 4,09 & 0,87 & 13,45 & 19,59 & 25,43 \\
\hline $\begin{array}{c}\text { EEDK } \\
222,2 \mathrm{mg} / \mathrm{kgBB}\end{array}$ & 2,49 & 5,41 & 7,69 & 10,25 & 12,53 \\
\hline $\begin{array}{c}\text { EEDK } \\
277,7 \text { mg/kgBB }\end{array}$ & 5,19 & 8,32 & 11,16 & 14,02 & 17,14 \\
\hline & 4,03 & 8,06 & 11,82 & 15,59 & 19,62 \\
\hline
\end{tabular}

Keterangan : EEDK (Ekstrak Etanol Daun Kamboja)

Tabel 3. Hasil analisis uji lanjutan LSD (Least Significant Different) pada kelompok perlakuan

\begin{tabular}{|c|c|c|c|}
\hline \multicolumn{2}{|c|}{ Kelompok perlakuan } & $\mathbf{P}$ & $\begin{array}{c}\text { Katerangan } \\
(p>0,05)\end{array}$ \\
\hline \multirow{4}{*}{ Na.CMC } & Nat. Diklofenak & 0,019 & $\mathrm{Bn}$ \\
\hline & EEDK $166,6 \mathrm{mg} / \mathrm{kgBB}$ & 0,224 & TBn \\
\hline & EEDK 222,2mg/kgBB & 0,044 & $\mathrm{Bn}$ \\
\hline & EEDK $277,7 \mathrm{mg} / \mathrm{kgBB}$ & 0,031 & $\mathrm{Bn}$ \\
\hline \multirow{3}{*}{ Natrium Diklofenak } & EEDK 166,mg/kgBB & 0,211 & TBn \\
\hline & EEDK 222,2mg/kgBB & 0,695 & TBn \\
\hline & EEDK $277,7 \mathrm{mg} / \mathrm{kgBB}$ & 0,825 & TBn \\
\hline \multirow{2}{*}{ EEDK 166, mg/kgBB } & EEDK 222,2mg/kgBB & 0,381 & TBn \\
\hline & EEDK $277,7 \mathrm{mg} / \mathrm{kgBB}$ & 0,299 & TBn \\
\hline EEDK 222,2mg/kgBB & EEDK $277,7 \mathrm{mg} / \mathrm{kgBB}$ & 0,865 & TBn \\
\hline
\end{tabular}

Keterangan : Bn (Barbeda nyata), Tbn (Tidak berbeda nyata), EEDK (Ekstrak etanol daun kamboja)

\section{PEMBAHASAN}

Pengujian antiinflamasi ekstrak etanol daun kamboja (Plumeria rubra L.) dilakukan dengan mengukur volume edema tikus yang diinduksi karagen $1 \%$ b/v secara intraplantar (telapak kaki). Pengukuran volume edema dilakukan menggunakan pletismometer dengan prinsip pengukuran berdasarkan hukum Archimedes yaitu benda yang dimasukkan ke dalam zat cair akan memberi gaya atau tekanan ke atas sebesar volume yang dipindahkan. 
Efek antiinflamasi ekstrak etanol daun kamboja (lumeria rubra L.) pada tikus putih (Rattus norvegicus)

Kaki kiri tikus dicelupkan ke dalam pletismometer dan dilihat kenaikan volume kakinya.

Zat yang digunakan sebagai penginduksi edema adalah karagen. Senyawa ini dapat menyebabkan terjadinya cedera sel dengan melepaskan mediator nyeri sehingga menimbulkan inflamasi. Hal ini disebabkan karena karagen merupakan senyawa hidrokoloif yang terdiri atas ester kalium, natrium dan magnesium atau kalsium sulfat dengan galaktosa dan kopolimer 3,6 anhidrogalaktosa. Senyawa ini mudah diterima oleh fisiologis tubuh sehingga respon inflamasi terjadi secara cepat dan memudahkan untuk diamati. Karagen bersifat netral yang hanya menyebabkan edema dan tidak menyebabkan nekrosis (kematian jaringan).

\section{Tanaman}

kamboja mengandung senyawa flavonoid. Flavonoid termasuk senyawa fenolik alam yang potensial besar sebagai antiinflamasi. Flavanoid mempunyai aktivitas antiinflamasi dengan menghambat beberapa enzim seperti aldose reduktase, xanthine oksidase phosphodiesterasem $\mathrm{Ca}^{2+}$ ATPase, lipooxygenase dan siklooksigenase. Untuk menguji kemampuan ekstrak etanol daun kamboja sebagai antiinflamasi, maka diujikan pada hewan coba tikus putih jantan.

Dalam penelitian ini digunakan tikus sebanyak 15 ekor yang dibagi dalam 5 kelompok perlakuan.Setiap kelompok terdiri dari 3 ekor tikus. Pengujian antiinflamasi dilakukan dengan cara menginduksi karagen $1 \%$ sebanyak $0,1 \mathrm{~mL}$ ditelapak kaki tikus. Setelah selang 1 jam kelompok I diberikan Na.CMC (kontrol negatif), kelompok II diberikan natrium diklofenak (kontrol positif), dimana natrium diklofenak merupakan golongan NSAID dengan aktivitas antiinflamasi, analgetik dan antipiretik. Mekanisme kerjanya adalah menghambat siklooksigenase secara nonselektif sehingga menghambat pembentukan prostaglandin. Natrium diklofenak merupakan derivate sederhana dari phenylacetic acid (asam fenilasetat) yang kuat antiradangnya dengan efek sampig yang ringan dibandingkan obat jenis lainnya, dan kelompok III, IV dan V diberikan ekstrak etanol daun kamboja dengan 3 dosis yang berbeda yaitu $166,6 \mathrm{mg} / \mathrm{kgBB}, 222,2 \mathrm{mg} / \mathrm{kgBB}$ dan 277,7 mg/kgBB. Selanjutnya pengukuran dilakukan dengan cara mengukur kemampuan daun kamboja dalam mengurangi pembengkakan 
Efek antiinflamasi ekstrak etanol daun kamboja (ㄹlumeria rubra L.) pada tikus putih (Rattus norvegicus)

kaki tikus selam 5 jam dengan interval waktu tiap 1 jam.

Tabel 1 merupakan hasil penurunan volume edema yang diamati setiap 1 jam selama 5 jam menunjukan semua kelompok perlakuan mengalami penurunan volume edema, termasuk kelompok Na.CMC hal ini mungkin disebabkan karena adanya respon tubuh dalam memperbaiki jaringan, sedangkan kelompok natrium diklofenak pada jam ke 1 mengalami penurunan sedangkan pada jam ke 2 volume edema mengalami kenaikan kembali, hal ini mungkin disebabkan karena kesalahan proses pencelupan kaki tikus. Untuk kelompok III, IV dan V menunjukan bahwa pada jam ke 1 sampai jam ke 5 mengalami penurunan volume edema pada kaki tikus.

Data dari tabel 1 kemudian dihitung persen penurunan volume edema setelah perlakuan pada jam ke5 yang hasilnya dapat dilihat pada tabel 2, melalui rumus persen penurunan berikut:

$$
\text { Persen edema }=\frac{\mathrm{Vo}-\mathrm{Vt}}{\mathrm{Vo}_{\mathrm{o}}} \times 100 \%
$$

Ket :

Vt: Volume edema setelah waktu $t$ Vo: Volume awal kaki tikus

$$
\text { Data rata-rata persen }
$$

penurunan volume edema pada tiap jam perlakuan dapat dilihat pada tabel

2. Dimana menunjukkan bahwa kelompok Na.CMC pada jam ke 5 memiliki rata-rata persen penurunan edema sebesar 4,91\%, kelompok natrium diklofenak memiliki rata-rata persen penurunan sebesar $25,43 \%$, sedangkan kelompok ekstrak etanol daun kamboja dosis 166,6 mg/kgBB, 222,2 $\mathrm{mg} / \mathrm{kgBB}$ dan 277,7 $\mathrm{mg} / \mathrm{kgBB}$ memiliki rata-rata persen penurunan sebesar $12,53 \%, 17,14 \%$ dan $19,62 \%$. Hal ini menunjukan bahwa kelompok ekstrak etanol dosis 166,6 mg/kgBB, $222,2 \mathrm{mg} / \mathrm{kgBB}$ dan 277,7 mg/kgBB memiliki efek antiinflamasi, tetapi tidak lebih baik dari pada natrium diklofenak. Kelompok ekstrak etanol dosis 277,7 mg/kgBB menunjukan persen penurunan volume edema kaki tikus paling besar dibandingkan dengan kelompok ekstrak etanol dosis 166,6 mg/kgBB dan 222,2 mg/kgBB yaitu sebesar $20,08 \%$..

Data dari setiap kelompok perlakuan diolah secara statistik menggunakan analisis one wayanova untuk menentukan perbedaan antara kelompok perlakuan. Dari pengamatan tersebut didapatkan niai signifikannya $\mathrm{p}=0,106$ yang artinya tidak terdapat perbedaan yang nyata antara tiap kelompok perlakuan. Analisis dilanjutkan dengan menggunakan uji 
Efek antiinflamasi ekstrak etanol daun kamboja (ㄹlumeria rubra L.) pada tikus putih (Rattus norvegicus)

LSD (Least square differences).Uji

LSD adalah uji untuk melihat perbedaan antara kelompok perlakuan. Dari pengamatan tersebut didapatkan niai signifikannya $p=0,106$ yang artinya tidak terdapat perbedaan yang nyata antara tiap kelompok perlakuan. Analisis dilanjutkan dengan menggunakan uji LSD (Least square differences).Uji LSD adalah uji untuk melihat perbedaan antara kelompok perlakuan. Berikut adalah tabel uji LSD.

Berdasarkan dari hasil uji LSD pada tabel 3menunjukan bahwa kelompok Na.CMC 1\% b/v terhadap kelompok natrium diklofenak dan ektrak etanol daun kamboja dosis $222,2 \mathrm{mg} / \mathrm{kgBB}$ dan 277,7 mg/kgBB secara statistik berbeda nyata dengan nilai signifikan $(p<0,05)$ yaitu 0,019 , 0,044 dan 0,31 , sedangkan kelompok ekstrak etanol daun kamboja dosis 166,6 mg/kgBBtidak menunjukkan perbedaan yang nyata. Hal ini berarti bahwa pada kelompok Na.CMC 1\% $\mathrm{b} / \mathrm{v}$ tidak memiliki efek antiinflamsi. Kelompok natrium diklofenak terhadap kelompok ekstrak uji secara statistik tidak berbeda nyata $(p>0,05)$ dengan nilai signifikan $0,211,0,695$ dan 0,825, hal ini berarti kelompok ekstrak etanol daun kamboja memiliki efek yang sama dengan natrium diklofenak dalam menurunkan volume edema, akan tetapi ekstrak uji tidak lebih baik dibandingkan natrium diklofenak. Kelompok perlakuan ekstrak etanol daun kamboja dosis 166,6 mg/kgBB terhadap kelompok ekstrak etanol daun kamboja dosis 222,2 $\mathrm{mg} / \mathrm{kgBB}$ dan $277,7 \mathrm{mg} / \mathrm{kgBB}$ secara statistik tidak berbeda nyata $(p>0,05)$ dengan nilai signifikan 0,381 dan 0,299 . Kelompok ekstrak etanol daun kamboja dosis 222,2 $\mathrm{mg} / \mathrm{kgBB}$ terhadap kelompok estrak etanol daun kamboja dosis $277,7 \mathrm{mg} / \mathrm{kgBB}$ secara statistik menunjukan hasil yang tidak berbeda nyata $(p>0,05)$ dengan nilai signifikan yaitu 0,865 , hal ini berarti kelompok ekstrak etanol daun kamboja memiliki efek yang sama dalam menurunkan volume edema/ menghambat inflamasi.

Dari hasil pengukuran volume edema dan uji statistik dapat disimpulkan bahwa ekstrak etanol daun kamboja (Plumeria rubra L.) pada dosis 166,6 mg/kgBB, 222,2 $\mathrm{mg} / \mathrm{kgBB}$ dan 277,7 mg/kgBB memiliki efek antiinflamsi dengan nilai signifikan $(p<0,05)$.

\section{KESIMPULAN}

Berdasarkan hasil penelitian dan analisis data maka dapat disimpulkan bahwa ektrak etanol daun kamboja (Plumeria rubra L.) memiliki aktivitas 
Efek antiinflamasi ekstrak etanol daun kamboja (lumeria rubra L.) pada tikus putih (Rattus norvegicus)

sebagai antiinflamasi. Ekstrak etanol daun kambojadosis 166,6 mg/kgBB, $222,2 \mathrm{mg} / \mathrm{kgBB}$ dan $277,7 \mathrm{mg} / \mathrm{kgBB}$ dapat menurunkan volume edema pada telapak kaki tikus.Ekstrak etanol daun kamboja yang memiliki efek paling baik sebagai antiinflamasi adalah dosis $277,7 \mathrm{mg} / \mathrm{kgBB}$.

\section{DAFTAR PUSTAKA}

1. Harvey AR, Champe CP. Farmakologi Ulasan Bergambar. Jakarta : Widya medika, 2014.

2. Corwin EJ. Buku Saku Patofisilogi, Departemen kesehatan. Jakarta : EGC, 2008.
3. Wilmana PF, Sulistia GG. Analgetik Antipiretik, Analgetik Antiinflamasi Non Steroid dan Obat Pirai, dalam Sulistia G.G. (ed). Jakarta: Bagian Farmakologi FKUI, 2007.

4. Tjay TH, Kirana R. Obat-Obat Penting Khasiat,Penggunaan dan Efek-Efek Sampingnya (Ed) VI. Jakarta : PT. Elex Media Komputindo, 2007.

5. Arief. Tanaman Obat dan Khasiatnya seri 3 edk 1.Jakarta, 2009.

6. Ahkam S, Muhammad. Real Food True Health (Makanan Sehat untuk Hidup Lebih Sehat). Jakarta : PT. AgroMedia Pustaka, 2008. 